\title{
EPIDEMIOLOGICAL ANALYSIS OF DENGUE'S INCIDENCE ON CERES-GO COUNTY BETWEEN 2012 AND 2015
}

Guilherme Petito ${ }^{1}$, Ana Flávia Mendes Pinheiro ${ }^{2}$, Igor Godinho Portis ${ }^{3}$, Thuany Carrijo Lisboa $^{2}$ and Anamaria Donato de Castro Petito ${ }^{4}$.

1. Docente da FACER- Faculdades Unidade de Ceres-GO, Brasil, cursos de Enfermagem e Farmácia - Mestre em Genética PUC-GO, Doutorando em Genética e Biologia Molecular Instituto de Ciências Biológicas 2 - UFG, Brasil.

guilherme.petito@hotmail.com

2. Acadêmica do Curso de Farmácia, FACER- Faculdades Unidade de Ceres-GO, Brasil

3. Mestre em Genética e Biologia Molecular - UFG, Doutorando em Genética e Biologia Molecular, Instituto de Ciências Biológicas 2 - UFG, Brasil.

4. Docente da FACER- Faculdades Unidade de Ceres-GO, departamento de Enfermagem, Brasil

\section{ABSTRACT}

Dengue is an infectious disease caused by a virus Flaviirus genus, transmitted by a vector, the Aedes aegypti. The aim of this study was promote an epidemiological study to identify the incidence of dengue cases reported in the city of Ceres, Goiás. Study was conducted epidemiological, descriptive, ecological type, cross-sectional, quantitative, accomplished by the data collection of the number of reported and confirmed cases of dengue, in the 2012 period to 2015 , provided by municipal surveillance in the city of Ceres, Goiás, and the site of the Goiás State Department of Health. Between 2012 to 2015 were reported 4556 dengue cases in the municipality of Ceres, and of these, $45.96 \%$ were confirmed by serological tests. Of the total cases reported during this period $(n=4.566), 50.53 \%(2.290)$ are the only cases reported in 2015 . The incidence rate of the disease in 2015, in Ceres, was 11.051 cases / 100.000 inhabitants, values surpass the previous years (2012-2014). This result demonstrates the high burden of disease in the population of this municipality in 2015. The data also suggest the addition of a new serotype in the region. This increase of the risk of dengue hemorrhagic fever, which characterized as a complication of classic disease, however, data for cases of dengue hemorrhagic fever were not available. There was a considerable increase in the number of dengue cases in 2015 compared to previous years, 2012 to 2014 . This growth 
suggests that serological studies focusing on serotypes detection should be conduct on region.

KEY WORDS: Aedes aegypti; serogroup; epidemics.

\section{INTRODUCTION}

Dengue is an infectious disease caused by a virus of the Flavivirus genus of the family Flaviviridae, transmitted by a vector, the mosquito Aedes aegypti, which is more spread in the summer due to the hot and humid climate favor their proliferation. The disease is characterized by joint pain, high fever, vomiting, diarrhea, among others, and may even develop into a more serious condition, dengue haemorrhagic (Wyse et al., 2011).

The adaptation of Aedes aegypti to the urban environment was favored by rural / urban flow. With the increase of population in cities and lack of health education of the population with domestic garbage, there is an increase of stagnant water deposits, especially in the rainy season, a fundamental factor for vector proliferation (Tauil, 2002).

For the diagnosis are used serologic tests to detect viral antigens or antibodies. The serological test it is used for detection of $\operatorname{IgM}$ and $\operatorname{IgG}$ antibodies. The first it is found when the patient is in the acute phase, or is infected with the disease. Since IgG is found in the body after healing of the disease, ie, it remains present in the body, giving the individual specific serotype specific immunity. Since viral test in order to identify the presence of NS1 antigen is used to detect the virus, allowing serotype is identified for which the patient was infected (Barros et al., 2008; Barreira et al., 2010).

The false diagnosis can occur because the initial symptoms are very similar to flu symptoms. Still, diagnosis based on medical observation without the aid of specific laboratory tests, also contribute to misdiagnosis which in turn influence the treatment of the disease (Figueiredo et al., 1992; De Souza et al., 2009).

The prevention of dengue should be encouraged more often at all times of the year, not only during rainy periods because these are time intervals that appear to most dengue outbreaks. The lack of health education is the main aggravating factor of epidemiological outbreaks (De Freitas Lenzi \& Coura, 2004). 
Health education about dengue is fundamental and basically involves simple care as leaving garbage exposed inappropriately, put sand in the plant dishes and cover the boxes of water, change the water plant pitchers twice a week, wash animal troughs daily, among others involving the observation of factors that favor the proliferation of mosquitoes (Souza et al., 2002; Lefèvre et al., 2004).

This study aimed to promote an epidemiological study to identify the incidence of dengue cases reported in the city of Ceres, Goiás.

\section{METHODS}

This is an observational epidemiological study of ecological, descriptive, crosssectional, quantitative, who conducted survey of the number of reported and confirmed cases of dengue in the period from 2012 to 2015. The survey was conducted in the public database, available by municipal surveillance in the city of Ceres, Goiás and the site of the State of Goiás State Health Secretariat. the data collected were stored in Microsoft Excel® and from this program were made Tables and Figure.

\section{RESULTS}

The data were collected in the epidemiological department of the Municipal Secretariat of Ceres, from information extracted from public database, and the site of the State Department of Health (Bulletin of Goiás Dengue). Reported cases are cases of reports that have been confirmed or not. Already confirmed cases, restricted to those confirmed by laboratory tests. The number of reported and confirmed cases was lower in the years 2012 and 2014 compared to the years 2013 and 2015 (Figure 1). In this study, 2015 data were collected through week 41, which is the week which runs from 05 October to 11 October this year. 


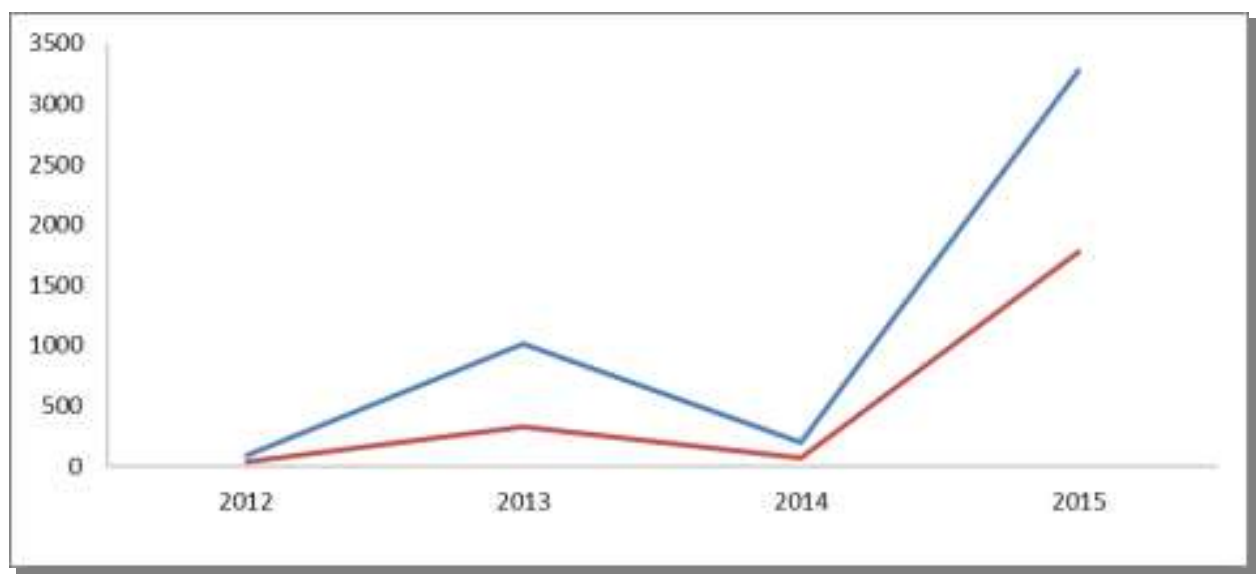

Figure 1 - Distribution of reported and confirmed cases of dengue in Ceres municipality from 2012 to 2015. Source: Municipal Surveillance Ceres City, Goiás

It was also rated the dengue incidence rate in the four years studied, in order to understand the relationship of the number of cases per capita group, thus being able to confirm the actual impact of the disease on the population in each year analyzed. The result shows the impact in 2015 compared to previous years, as shown in Table 1.

Table 1 - Incidence coefficient for Dengue cases confirmed between 2012-2015.

\begin{tabular}{lc}
\hline Year & Incidence rate for 100.000 inhabitants** \\
\hline 2012 & 82 \\
2013 & 1.109 \\
2014 & 352 \\
$2015^{*}$ & 11.051 \\
\hline
\end{tabular}

* Confirmed cases of week 41/2015.

** Estimated population of 20.722 for the period to calculate the incidence rate, according to IBGE 2010.

The relationship between the municipalities with the highest number of dengue cases in Goiás, registered until week 41 2015, Ceres appears in 10th place, confirming the impact of the disease in the municipality also in relation to other municipalities. In the same ranking, the three cities with the highest number of cases were Goiânia, Aparecida de Goiania and Anapolis (Table 2).

The table 3 presents the comparison of the incidence rate of Ceres, with the three municipalities with the highest number of dengue cases in 2015. 
Table 2 - Municipalities with higher dengue cases numbers in Goiás, registered until week 41 of 2015.

\begin{tabular}{lll}
\hline Ranking & City & Frequency \\
\hline $1^{\mathbf{o}}$ & Goiânia & 79.917 \\
$2^{\mathrm{o}}$ & Aparecida de Goiânia & 14.673 \\
$3^{\mathrm{o}}$ & Anápolis & 10.112 \\
$4^{\mathrm{o}}$ & Jataí & 4.906 \\
$5^{\mathrm{o}}$ & Rio Verde & 3.954 \\
$6^{\mathbf{0}}$ & Mineiros & 3.380 \\
$7^{\mathrm{o}}$ & Goianira & 3.044 \\
$8^{\mathrm{o}}$ & Goiatuba & 3.020 \\
$9^{\circ}$ & Valparaíso de Goiás & 2.518 \\
$10^{\circ}$ & Ceres & 2.290 \\
\hline
\end{tabular}

Table 3 - Comparison of the incidence rate of Ceres, with the three municipalities with the highest number of dengue cases in 2015.

\begin{tabular}{lll}
\hline City & Population* & Incidence rate \\
\hline Ceres & 20.722 & $11.051 / 100000$ inhabitants \\
Goiânia & 1.430 .697 & $5.585 / 100000$ inhabitants \\
Aparecida de Goiânia & 521.910 & $2.811 / 100000$ inhabitants \\
Anápolis & 366.491 & $2.759 / 100000$ inhabitants \\
\hline
\end{tabular}

* Brazilian Institute of Geography and Statistics.

\section{DISCUSSION}

Between the years 2012-2015 there was variation between the numbers of reported cases. Studies suggest that these variations are common in diseases such as dengue, a fact characterized by the entry of new serotypes, changes in the population's immunization profile, preventive behavior of the population, among others (Dos Santos et al., 2011; Lucena et al., 2011; Da Costa, 2013). 
Year data 2015 represented above, the absolute number of total cases, and the impact of that number in the population (incidence coefficient) suggests the entry of a new serotype in the region. People never before exposed to one serotype are much more susceptible to epidemics, because they still do not have immunity to the new serotype (Costa et al., 2011; SES-SP, 2014).

In addition to the entry of a new serotype, care of the population, as well as supervision by public bodies in the control of factors that favor increased mosquito, is another important aspect for the control of infectious disease epidemics such as dengue. Failure to comply with these standards increases the possibility of spreading disease (Barreto \& Teixeira, 2008).

This increase raises the risk of dengue hemorrhagic fever, which is characterized as a complication of classic disease, the main symptoms gingival bleeding, nasal, vaginal and rupture of vessels in the skin, is more serious, but rarely progresses to death (Casali et al., 2004; De Sá Rocha et al., 2011). The risk is higher in people who already had dengue because specific antibodies will not be able to neutralize a different virus, and when bind to the virus will facilitate large amount of input virus in macrophages (Dias et al., 2010).

According to the data in Table 3, the Ceres situation is worrying because although the population of Ceres to be much smaller than the other municipalities, it presents a much higher number of dengue cases.

The incidence rate expresses the real impact of the disease on the population and indicates the risk of contracting such a disease in a particular region (Sabroza \& SouzaSantos, 2010). In this scenario, it is evident that in the Ceres district, in 2015, the risk of contracting dengue was higher than in populated cities like Goiania and Anapolis (Reis et al., 2013).

\section{CONCLUSION}

The year 2015 was atypical compared to previous years in relation to infection by the dengue virus. This increase reinforces the importance of more effective action by the population and public bodies in relation to this disease. This indicates the possible entry of a serotype hitherto not prevalent in the region, suggesting that serological studies are carried out in the municipality of Ceres, Goiás. 


\section{REFERENCES}

1. Barreira LAC, Machado AM, Aquino VH, Badra SJ, Figueiredo LTM. Padronização e uso de um método imunoenzimático que utiliza células infectadas como antígeno no diagnóstico rotineiro do dengue. Rev Soc Bras Med Trop, v. 43, n. 3, p. 268-271, 2010.

2. Barreto ML, Teixeira MG. Dengue no Brasil: situação epidemiológica e contribuições para uma agenda de pesquisa. Estud av v. 22, n. 64, p. 53-72, 2008.

3. Barros LPS, Igawa SES, Jocundo SY, Júnior LCB. Análise crítica dos achados hematológicos e sorológicos de pacientes com suspeita de Dengue. Rev Bras Hematol Hemoter, v. 30, n. 5, p. 363-366, 2008.

4. Casali CG, Pereira MRR, Santos LMJG, Passos MNP, Fortes BPMD, Valencia LIO, Alexandre AJ, Medronho RA. A epidemia de dengue/dengue hemorrágico no município do Rio de Janeiro, 2001/2002. Rev Soc Bras Med Trop, v. 37, n. 4, p. 296-9, 2004.

5. Costa AG, Santos JD, da Conceição JKT, Alecrim PH, Casseb AA, Batista WC, Heckmann MIO. Dengue: aspectos epidemiológicos e o primeiro surto ocorrido na região do Médio Solimões, Coari, Estado do Amazonas, no período de 2008 a 2009. Rev Soc Bras Med Trop, v. 44, n. 4, p. 471-474, 2011.

6. Da Costa GC. Modelo dinâmico para propagação de múltiplos sorotipos da dengue, 2013.

7. De Freitas LM, Coura LC. Prevenção da dengue: a informação em foco. Rev Soc Bras Med Trop, v. 37, n. 4, p. 343-350, 2004.

8. De Sá Rocha AP, Neto ADM, Arruda ALRP, Pires FDS, Huacho GLCC, Oliveira LCC, Tannus MM, Rodrigues RRG, Marques RBA. Dengue: história natural e definição de casos graves e potencialmente graves. Rev Med Minas Gerais, v. 31160, p. $370,2011$.

9. De Souza LJ, Rocha NSM, Campos TF, Silva FS, Souza LA. Velocidade de hemossedimentação na dengue: rastreio e prognóstico. Rev Soc Bras Clín Méd, v. 7, p. 309-312, 2009.

10. Dias LBA, de Almeida SCL, de Haes TM, Mota LM, Roriz-Filho JS. Dengue: transmissão, aspectos clínicos, diagnóstico e tratamento. Medicina (Ribeirão Preto. 
Online), v. 43, n. 2, p. 143-152, 2010. Available at: http://revista.fmrp.usp.br/2010/vol43n2/Simp6 Dengue.pdf. Acessed at 05/11/2015.

11. Dos Santos SL, Cabral ACSP, Da Silva ALG. Conhecimento, atitude e prática sobre dengue, seu vetor e ações de controle em uma comunidade urbana do Nordeste. Rev Ciênc Saúde Colet, v. 16, 2011.

12. Figueiredo LTM, Owa MA, Carlucci RH. Estudo sobre diagnóstico laboratorial e sintomas do dengue, durante epidemia ocorrida na região de Ribeirão Preto, SP, Brasil. Rev Inst Med Trop São Paulo, v. 34, p. 121-30, 1992.

13. Lefèvre F, Lefèvre AMC, Scandar SAS, Yassumaro S. Representações sociais sobre relações entre vasos de plantas e o vetor da dengue. Rev Saúde Pública, v. 38, n. 3, p. 405-14, 2004.

14. De Lucena LT, Aguiar LO, Bogoevich ACA, de Azevedo FS, dos Santos ACP, do Vale DBAP, Pereira DB, Villalobos-Salcedo JM . Dengue na Amazônia: aspectos epidemiológicos no Estado de Rondônia, Brasil, de 1999 a 2010. Rev Pan-Amaz Saúde, v. 2, n. 3, p. 19-25, 2011.

15. Reis CB, de Andrade SMO, da Cunha RV. Aliados do A. Aegypti: fatores contribuintes para a ocorrência do dengue segundo as representações sociais dos profissionais das equipes de saúde da família. Rev Ciênc Saúde Colet, v. 18, n. 2, p. 517-526, 2013.

16. Sabroza PC, Souza-Santos R. Determinação de áreas prioritárias para ações de controle da dengue. Rev Saúde Pública, v. 44, n. 2, p. 274-82, 2010.

17. SES-SP (Secretaria da Saúde - SÃO PAULO), Plano de vigilância, prevenção e controle da dengue do Estado de São Paulo 2014-2015, 2014.

18. Souza GS, Ramos MHC, Moraes RL, Pedroza SB, Silva-Pelissari SO, Moreira WMQ, Guimarães E, Cardoso JIM. Saúde, informação e cidadania epidemia de “dengue”. Ciências Biológicas, Rev Hispeci \& Lema, p. 33, 2002.

19. Tauil PL. Aspectos críticos do controle do dengue no Brasil Critical aspects of dengue control in Brazil. Cad Saúde Pública, v. 18, n. 3, p. 867-871, 2002.

20. Wyse APP, Gemaque AO, Chamilco GEI. Modelo Matemático da Transmissão de Dengue. Biomatemática v. 21, p. 153-162, 2011. 
REFACER v. 5, n. 2, 2016. ISSN - 2317-1367 